\title{
Levantamento soro-epidemiológico da infecção pelo vírus da Anemia Infecciosa Eqüina, da Influenza Eqüina-2 e do Herpesvírus Eqüino-1 em rebanhos do sul do Estado do Pará, Brasil
}

Lindomar José PENA ${ }^{1}$

Darlene Aparecida PENA ${ }^{2}$

Priscilla Rochele BARRIOS ${ }^{3}$

Renato DALE'

Márcia Rogéria de Almeida LAMÊEGO $^{2}$

Mauro Pires MORAES ${ }^{1}$

Correspondência para:

MAUROPIRESMORAES

Departamento de Veterinária

Centro de Ciências Biológicas e da Saúde

Universidade Federal de Viçosa

Campus Universitario - Centro

36571-000-Vicosa-MG

mpmoraes@ufv.br

Recebido para publicação: 27/09/2004 Aprovado para publicação: 13/07/2005

1- Departamento de Medicina Veterinária da Universidade Federal de Viçosa, Viçosa - MG

2 - Departamento de Bioquímica e Biologia Molecular da Universidade Federal de Viçosa, Viçosa - MG

3 - Departamento de Microbiologia Agrícola da Universidade Federal de Viçosa, Viçosa - MG

\section{Resumo \\ Os vírus da anemia infecciosa eqüina (EIAV), da influenza eqüina tipo 2 (EIV-2) e o herpesvírus eqüino tipo 1 (EHV-1) são agentes causadores de enfermidades que podem causar graves prejuízos econômicos. O objetivo deste presente estudo foi estimar a freqüência de anticorpos contra o EIAV, EIV-2 e o EHV-1 em rebanhos do sul do Estado do Pará, Brasil. Os anticorpos contra EIAV, EIV-2 e EHV- 1 foram detectados pelo teste de IDGA, pelo método de inibição da hemaglutinação e pela técnica de soroneutralização $\left(\operatorname{TCID}_{50}=100\right)$, respectivamente. Amostras de sangue de 672, 514 e de 506 equídeos saudáveis e sem histórico de vacinação contra nenhum dos três vírus foram testadas, respectivamente, para EIAV, EIV-2, EHV-1. A seguinte freqüência de soro reativos foi observada: $1,34 \%$ para o EIAV; $35,79 \%$ para o EIV-2; 45,45\% para o EHV-1. Estes resultados indicam que estes agentes estão presentes no rebanho paraense e a adoção de medidas de manejo e profilaxia devem ser priorizadas, garantindo deste modo, a prosperidade da eqüideocultura brasileira.}

\section{Introdução}

A Anemia Infecciosa Eqüina (AIE) é considerada a principal doença infecto-contagiosa da equideocultura brasileira, para a qual não há vacina e nem tratamento eficaz ${ }^{1}$.

$\mathrm{O}$ vírus da AIE (EIAV) pertence à família Retroviridade, gênero Lentivirus. O seu genoma é constituído por uma dupla-fita de RNA senso positivo ${ }^{2}$. O EIAV possui duas glicoproteínas no envelope, Gp 45 e Gp 90, e quatro glicoproteínas no nucleocapsídeo, sendo a p26 a mais importante para o diagnóstico sorológico, uma vez que é um grupo-reativo antigenicamente estável ${ }^{3}$. Contra esta glicoproteína foi desenvolvido um prova de imunodifusão em ágar gel (IDGA) para detectar anticorpos precipitantes ${ }^{4}$. Este teste continua sendo o único método reconhecido oficialmente pela Organização Internacional de Epizootias (OIE) ${ }^{3}$ e pelo Ministério da Agricultura, Pecuária e Abastecimento (MAPA) para o diagnóstico de AIE e somente pode ser realizado em laboratórios credenciados pelo MAPA ${ }^{5}$.

Uma ampla resposta imune humoral é detectada na maioria dos equídeos infectados contra as glicoproteínas Gp 45 e Gp 90. Apesar da rápida geração de variantes antigênicas do EIAV durante infecção in vivo, muitos animais infectados suprimem a replicação viral e tornam-se portadores assintomáticos ${ }^{6}$.

A Influenza é considerada a mais importante doença do aparelho respiratório 
dos equídeos sob o ponto de vista econômico ${ }^{7}$. Na América do Norte, com exceção da cólica, a Influenza Eqüina é a enfermidade que mais necessita de assistência veterinária ${ }^{8}$. É uma enfermidade de distribuição cosmopolita (exceto Austrália, Nova Zelândia e Islândia) e se caracteriza epidemiologicamente por alta morbidade e baixa letalidade?

A doença é causada pelo vírus da Influenza Eqüina (EIV). Este agente pertence à família Orthomyxoviridae, gênero Influenza $A$. No seu envelope estão presentes as glicoproteínas hemaglutinina e neuraminidase. A hemaglutinina é o principal imunógeno, uma vez que os anticorpos anti-hemaglutinina podem interceptar e neutralizar a adsorção viral. São estes antígenos que permitem a diferenciação entre os dois subtipos distintos antigenicamente: A/equi/1(H7N7) e A/ equi/2(H3N8). O EIV-2 tem sido identificado na maioria dos surtos descritos, enquanto que o EIV-1 foi descrito pela última vez em $1979^{10}$.

Em equídeos susceptíveis, num período de 24 a 48 horas pós-infecção, a doença se manifesta clinicamente por febre, depressão, anorexia, tosse seca e exsudação nasal serosa. A infecção primária é freqüentemente complicada por infecções bacterianas secundária, como por Streptococus zooepidemicus, Pasteurela spp. e, ou, Actinobacillus $s p p^{11}$.

O Herpesvírus Eqüino-1 (EHV-1) pertence à familia Herpesviridade, subfamília Alphaherpesvirinae. São vírus envelopados e possuem genoma de DNA dupla-fita ${ }^{12}$. O EHV-1 causa doença respiratória, abortamento, doença neonatal e doença neurológica ${ }^{13}$. A doença respiratória induzida pelo EHV-1 é caracterizada por sinais clínicos similares à Influenza, embora ela seja considerada mais branda ${ }^{7}$. O impacto econômico da infecção pelo EHV-1 pode ser devastador, particularmente quando ocorrem abortamentos epizoóticos ${ }^{14}$.

A principal forma de transmissão do agente é através da inalação de aerossóis por eqüinos susceptíveis e, após a infecção, o
EHV-1 é capaz de estabelecer latência no hospedeiro e a recrudescência ocorre normalmente após situações de estresse ${ }^{13,14}$.

De maneira geral, existem poucas informações sobre a sanidade animal no ecossistema tropical úmido. Mesmo que determinadas afecções de origem infecciosa e, ou, parasitária sejam bem documentadas em outros ecossistemas, é bem provável que o ambiente amazônico apresente peculiaridades que interfiram em seu perfil epidemiológico.

Devido à ausência de dados sobre a ocorrência destas viroses no estado do Pará e como um primeiro passo na compreensão de suas características epidemiológicas nesta região, o objetivo deste trabalho foi estimar a freqüência de anticorpos contra o EIAV, EIV-2 e EHV-1 em equídeos no estado do Pará.

\section{Materiais e Métodos}

\section{Colheita das amostras}

Amostras de sangue foram coletadas de 672 equídeos de dupla aptidão, oriundos de propriedades do sul do estado do Pará. Os equídeos não apresentavam histórico de vacinação contra nenhum dos agravos estudados. No momento da colheita não foram observadas manifestações clínicas características das infecções pelo EIAV, EIV2 e EHV-1 . O material foi transportado sob refrigeração até o Laboratório de Virologia do Departamento de Medicina Veterinária da Universidade Federal de Viçosa, onde após a obtenção do soro por centrifugação, o mesmo foi estocado a $-20^{\circ}$ C para posterior realização das provas sorológicas.

\section{Deteç̧ão de anticorpos anti-EIAV}

Amostra de soro de 672 equídeos foram testadas através do teste de COGGINS. A prova de IDGA foi realizada em placas de Petri onde uma solução de agarose $1 \%$ foi semeada e, após a solidificação do ágar, foram efetuadas pequenas perfurações com um picotador de 
gel em roseta ( 6 orifícios periféricos e 1 central). $\mathrm{Na}$ cavidade central colocou-se o antígeno comercial aprovado pelo MAPA e nas 6 cavidades periféricas foram adicionadas as amostras de soro a serem testadas. A placa de Petri foi incubada em câmara úmida e após 48 horas foi realizada a leitura. Os soros foram considerados positivos quando houve a formação de uma banda de precipitação nítida.

\section{Detecção de anticorpos anti-EIV-2}

Foram analisadas 514 amostras de soro através da técnica de Inibição da Hemaglutinação (HI). Previamente ao teste, o soro foi inativado a $56^{\circ} \mathrm{C}$ por 30 minutos e, então, tratado por 30 minutos com Kaolin $25 \%$ e suspensão de hemácias de galinha $50 \%$. Em seguida, centrifugou-se a mistura e o sobrenadante foi coletado e estocado a $-20^{\circ} \mathrm{C}$ até o momento do uso.

A prova de HI foi realizada em microplacas de poliestireno de 96 cavidades com fundo em "V". Cada soro foi diluído em série com razão 2, sendo a primeira diluição de 1:5 e a última de 1:640. Em cada diluição foram adicionado $25 \mathrm{~mL}$ de vírus Influenza Eqüina/Santa Maria/2/88 com título padronizado para 8 unidades hemaglutinantes e incubou-se a microplaca por 15 minutos à temperatura ambiente. Em seguida, foram adicionadas $50 \mathrm{~mL}$ de hemácias de galinha 1\% e, após 1 hora de incubação à temperatura ambiente, procedeu-se à leitura. $\mathrm{O}$ título inibidor foi definido a partir do inverso da maior diluição do soro capaz de inibir completamente a atividade hemaglutinante. Os animais com títulos de anticorpos iguais ou superiores a $10 \mathrm{HI}$ foram considerados positivos para Influenza Eqüina.

\section{Detecção de anticorpos anti -Herpesvírus Eqüino tipo 1}

A detecção de anticorpos contra o EHV-1 foi realizada pela microtécnica de soroneutralização viral. Foram testadas 506 amostras de soro através deste método.

$\mathrm{O}$ ensaio foi realizado em microplacas de 96 cavidades. Cada soro-teste foi incubado com 100 TCID $_{50}$ da amostra Kentucky do EHV-1 por 1 hora a $37^{\circ} \mathrm{C}$ em atmosfera de $5 \%$ de $\mathrm{CO}_{2}$ Posteriormente, a mistura foi adicionada em culturas de células da linhagem VERO e o cultivo foi monitorado por 72 horas para observação do efeito citopático. Caso o soro possua anticorpos (animal positivo), o vírus será neutralizado e não produzirá o efeito citopático. O título soro-neutralizante foi determinado pela maior diluição do soro capaz de inibir 100\% do efeito citopático induzido pelo EHV-1 nas células VERO.

\section{Resultados e Discussão}

A freqüência de anticorpos contra as três viroses está apresentada na figura 1. Os resultados obtidos em relação ao EIAV das 672 amostras testadas foram encontrados 9 positivas, o que equivale a 1,34\% dos animais. Este resultado demonstra que este agente, apesar dos programas de controle, ainda permanece no rebanho brasileiro, especialmente no ecossistema tropical úmido, que é ecologicamente propício para o desenvolvimento de insetos hematófagos, os quais constituem um fator de grande importância na determinação do grau de endemicidade da doença ${ }^{16}$.

Também investigando a freqüência de anticorpos contra o EIAV no estado do Pará, Heinemann et al. ${ }^{16}$, no ano de 2002, encontrou $17,71 \%$ de eqüinos soro reativos no município de Uruará. A ocorrência de anticorpos contra o EIAV também foi pesquisada por Dias em 2000 (apud HEINEMANN et al., 2002) ${ }^{16}$ que detectou $28,53 \%$ de animais soro positivos na Ilha de Marajó, 10,70\% em Santa Maria do Pará e 25,00\% em Paragominas. Através destes resultados pode-se inferir que a infecção ocorre em uma ampla área geográfica do estado.

Considerando que mais de $95 \%$ dos animais infectados por EIAV são portadores assintomáticos, o diagnóstico laboratorial assume um papel decisivo no controle e prevenção da Anemia Infecciosa Eqüina. Os anticorpos contra a nucleoproteína p26 podem ser detectados através do teste de IDGA, na 
maioria dos equídeos infectados, entre 15 a 31 dias pós-infecção e permanecem indefinidamente ${ }^{5}$.

No que tange à pesquisa de anticorpos contra o EIV-2, a ocorrência de 35,79\% (184/ 514) de equídeos soro reagentes encontrada no presente estudo revela a ampla disseminação do vírus na população analisada.

No Brasil, cujo clima é predominantemente tropical, a Influenza não é tão grave quanto nos países de clima temperado ${ }^{17}$. Por outro lado, o controle de surtos é praticamente impossível pelas características explosivas do mesmo. Esta condição reflete a necessidade de adoção de medidas de controle e profilaxia, como o isolamento de animais infectados, quarentena e sorologia daqueles recém adquiridos pela propriedade, pois muitas epidemias de influenza originaram-se da introdução de animais subclinicamente infectados que estavam eliminando o agente etiológico. Embora o uso intensivo de vacinação no hemisfério norte tenha auxiliado na redução dos índices de morbidade e da severidade da doença clínica, muitos surtos de Influenza foram ainda descritos, especialmente após a emergência de uma nova variante antigênica do vírus ${ }^{11}$. Em função disto, novas vacinas estão sendo desenvolvidas com a incorporação do EIV-1 e do EIV-2 subtipos europeu e americano. A referida vacina contém EIV-2 isolados da década de 90 e induz uma resposta imune com altos títulos de anticorpos que persistem por 26 semanas após a $3^{\mathrm{a}}$ vacinação ${ }^{7}$.

É importante enfatizar que as vacinas comerciais contra a Influenza necessitam ser modificadas periodicamente a fim de se assegurar a incorporação de tipos virais intimamente relacionados àqueles circulantes no campo.

A pesquisa de anticorpos contra o EHV1 revelou que 230 amostras das 506 testadas $(45,45 \%)$ possuíam anticorpos contra o referido vírus, indicando que o agente está disseminado na população estudada. Estes dados reforçam os achados de Heinemann et al., 2002 $2^{16}$, que detectaram uma prevalência de $17,71 \%$ no município de Uruará e por Dias em 2000 (apud HEINEMANN et al., 2002) ${ }^{16}$ que encontraram $21,70 \%$ e $13,18 \%$ de animais soro reativos na Ilha de Marajó e no restante do estado do Pará, respectivamente.

A capacidade do EHV-1 persistir no organismo de seu hospedeiro em estado latente é de particular importância na epizootiologia singular deste agravo. $\mathrm{O}$ estabelecimento de infecções latentes permite a persistência do agente até mesmo em rebanhos fechados através dos animais portadores, que são capazes de eliminar o vírus após estimulação apropriada ${ }^{12}$. Portanto, a adoção de medidas de manejo e profilaxia devem ser priorizadas uma vez que a doença

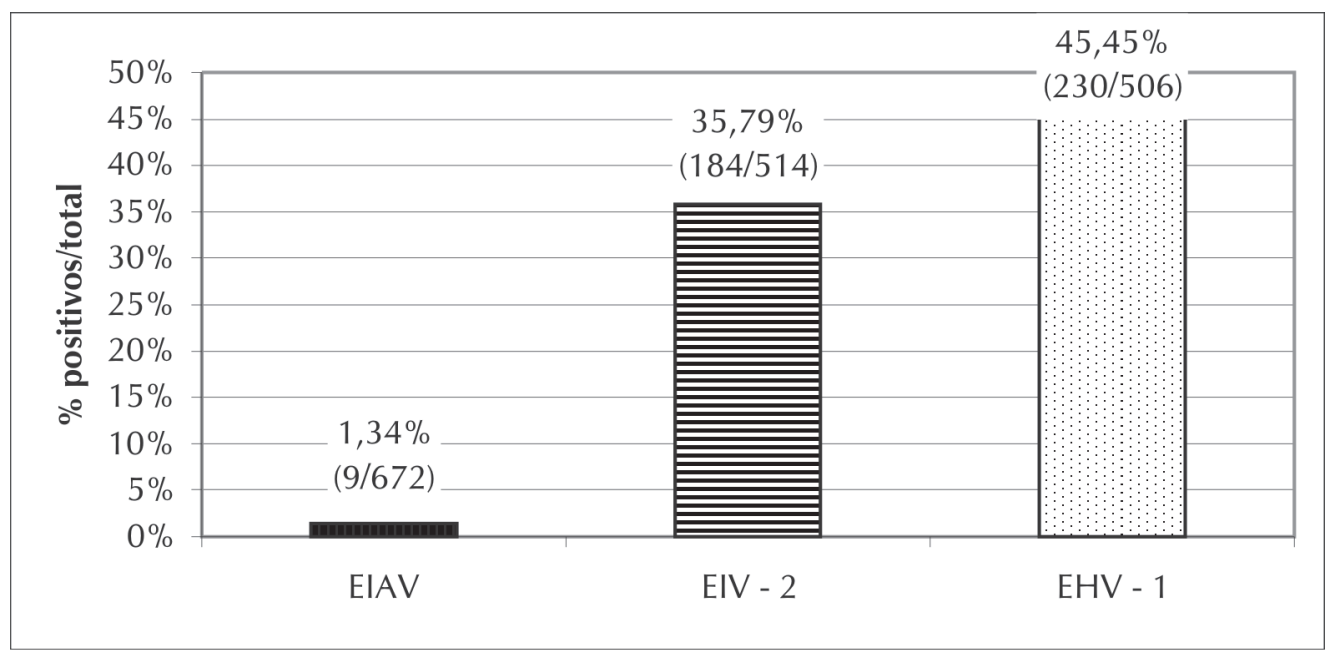

Figura 1- Frequência de animais soro-positivos contra EIAV, EIV-2 eEHV-1 
pode representar riscos de perdas por abortamentos, mortalidade perinatal, meningoencefalite e distúrbios respiratórios.

\section{Conclusão}

Com os resultados obtidos no presente levantamento, conclui-se que os
EIAV, EIV-2 e o EHV-1 estão presentes na população de equídeos no sul do Pará. Frente à importância social e econômica da criação de equídeos no Brasil, é essencial a destinação de recursos físicos e financeiros para a promoção de políticas sanitárias de combate a estas viroses, garantindo, desta maneira, a prosperidade da eqüideocultura brasileira.

\title{
Seroepidemiological survey of infection of equine infectious anemia, equine influenza type 2 and equine herpesvirus type 1 in herds of south Pará State, Brazil
}

\begin{abstract}
Equine infectious anemia virus (EIAV), equine influenza virus type 2 (EIV-2) and equine herpesvirus type 1 (EHV-1) are the causal agents of diseases that may bring economical losses. The aim of this present study was to estimate the frequency of antibodies against EIAV, EIV-2 and EHV-1 in herds of south Pará State, Brazil. Antibodies against EIAV, EIV-2 and EHV-1 were detected by AGID, hemagglutination inhibition method and serum neutralization technique $\left(\mathrm{TCID}_{50}=100\right)$, respectively. Blood samples of 572, 514, and 506 healthy equine unvaccinated against any of the three viruses were tested, respectively, for EIAV, EIV-2 and EHV-1. The following frequencies of serum reactors animals were observed: EIAV,1,34\%; EIV-2, 35,79\%; EHV-1, 45,45\%. These results show that the agents are present in herds from Pará herds and the adoption of measures of management and prophylaxis should be prioritized, ensuring, thereby, the prosperity of brazilian's breeding equine.
\end{abstract}

Key-words:

Equine.

\section{Referências}

1 SANTOS, R. M. L.; REIS, J. K. P.; SANTOS, F. G. A.; OLIVEIRA, I. C. S. Freqüência de anemia infecciosa eqüina em eqüinos no Acre, 1986 a 1996. Arquivo Brasileiro de Medicina Veterinária e Zootecnia, v. 53, n. 3, 2001.

2 MURPHY, F. A.; GIBBS, E. P. J.; HORZINEK, M. C.; STUDDERT,M. J. Veterinary Virology, 3. ed. 628 p. San Diego: Academic Press, 1999.

3 SOUTULLO, A; VERWIIMP, V.; RIVEROS, M.; PAULI, R.; TONARELLI, G. Design and validation of an ELISA for equine infectious anemia (EIA) diagnosis using synthetic peptides. Veterinary Microbiology, v. 79, p. 111-121, 2001.

4 COGGINS, L.; NORCROSS, N. L.; NUSBAUM, S. R.Diagnosis of equine infeccious anemia by immunodiffusion test. American Journal Veterinary Research, v. 9, p. 11-18, 1972.

5 CARVALHO, R. Situação do programa de controle e erradicação da anemia infecciosa eqüina em Minas
Gerais. Veterinária e Zootecnia em Minas Gerais. Publicação oficial do Conselho Regional de Medicina Veterinária do estado de Minas Gerais, n. 75, 2002.

6 SELLON, D. C.; FULLER, F. J.; MCGUIRE, T. C. The immunopathogenesis of equine infectious anemia virus. Virus Research, v. 32, p. 111-138, 1994.

7 HELDENS, J. G. M.; POUWELS, H. G. W.; VAN LOON, A. A. W. M. Efficacy and duration of immunity of a combined equine influenza and equine herpesvirus vaccine against challenge with an american like equine influenza virus (A/equi-2/Kentucky/95). The Veterinary Journal, v. 167,n.2, p. 150-157, 2004.

8 OLSEN, C. W. DNA vaccination against influenza viruses: a review with emphasis on equine and swine influenza. Veterinary Microbiology, v. 74, p. 149-164, 2000.

9 CUNHA, R. G., PAGANO, W .S. Comparação antigênica de três amostras de vírus da Influenza eqüina A/equi2, isoladas no Brasil. Pesquisa Veterinária Brasileira, v. 13,p.41-44,1993.

10 WILSON, W. D. Equine influenza. The Veterinary Clinics of North America: Equine Practice, v. 9, n. 2, 
1993.

11 TIMONEY, P. J. Equine influenza. Comparative immunology microbiology infectious diseases, v.19, n. 3, p. 205-211, 1996.

12 PANDEY, R. Microbiologia veterinária: perspectivas clinicas e moleculares. São Paulo: Editora Roca, 1994, v. 2, p. 77-133.

13 CARVALHO, R.; OLIVEIRA, A. M.; SOUZA, A. M.; PASSOS, L. M. F.; MARTINS, A. S. Prevalence of equine herpesvirus type 1 latency detected by polymerase chain reaction. Archives of virology, v. 145, p. 1773-1787, 2000.

14 OSTLUND, E. N. The equine herpesviruses. The Veterinary Clinics of North America: Equine Practice, v. 9, n. 2, 1993.

15 RIET-CORREA, F.; SHILD, A. L.; MENDEZ, M. D. C.; LEMOS, R.A.A. Doenças de ruminantes e eqüinos. 2 .. ed. São Paulo: Livraria Varela, 2001. v.1, 426 p.

16 HEINEMANN, M. B. et al. Soroprevalência da anemia infecciosa equina, da arterite viral dos equinos e do aborto viral equino no municipio de Uruará, PA, Brasil. Brazilian Journal Veterinary Research and animal SCience. Res. Anim. Sci., V.39, n. 1, 2002.

17 THOMASSIAN, A. Enfermidades dos cavalos. 3. ed. São Paulo: Livraria Varela,1997 p. 591-592 . 